\title{
The Stages of Recovery from Trauma after an Industrial Disaster
}

\author{
Anna L. Prehoda ${ }^{1,2}$ \\ ${ }^{1}$ Department of Social Sciences, Faculty of Sociology, Eotvos Lorand University, Hungary \\ ${ }^{2}$ Department of Social Sciences, Faculty of Sociology, Pazmany Peter Catholic University, Hungary
}

Copyright $\mathrm{O} 2016$ by authors, all rights reserved. Authors agree that this article remains permanently open access under the terms of the Creative Commons Attribution License 4.0 International License

\begin{abstract}
In this paper I would like to point out the typical stages of recovery from trauma after an industrial disaster. My research results are based on a comparative analysis between two interviewing period (first in 2010 and second in 2013). The interviews have been taken with affected people after the most wrecker industrial disaster ever in Hungary, named as "red sludge disaster". The uniqueness of my research is that I recorded my first interviews very shortly (within one and a half month) after the traumatic event with life story method, thus I had chance to complete my research with a participant observation as well. After the second period of interview making in 2013, my goal was to reveal what is the trauma-coping by affected people like, within a longer time after the case. I give a conceptual clarification of the notion of trauma. This notion is inseparable from the process of memory work. Hence I give a brief explanation also of this notion. I would like to underline the importance of Hungarian specialized literature of this two research areas in the last few decades. After analysing my data I have found three main stadiums in the coping process, what I name as 1.) phase of connecting, 2.) phase of cleaning and 3.) phase of various practices. My conclusion is, that the truly effective trauma-coping needs to use not only behavioural methods but mental interpretations as well.
\end{abstract}

Keywords Personal and Collective Trauma, Coping with Trauma, Personal and Collective Memory, Narrative Identity, Industrial Disaster, Red Sludge Disaster

\section{Introduction}

On 4 October 2010, in the Ajka micro-region, the red sludge catastrophe had devastating social and ecological consequences. Approximately one million cubic metres of strongly caustic toxic red sludge spilled over several settlements on this autumn day. The events were followed by more than three years of settling of loss, compensation and renovation works on the settlements most severely affected. The disaster was caused by the collapse of one of the reservoir dams of the company MAL Hungarian Aluminium. The catastrophe also caused several losses of human life in the area.

The examination of the ecological consequences of the event started shortly after the occurrence of the tragedy. Numerous negative ecological effects of the red sludge spill have been revealed: severe damage to the arable lands of the inundated area, and the extinction of the entire ecosystem of the Torna stream, to name just those of the greatest importance. The reason for the latter was that the red sludge directly spilled into the stream, and most of the fluid found its way to the settlements in the watercourse. Ecological consequences usually have social effects as well, so, after such an event, secondary damages also have to be taken into consideration. An example for this is the increased concentration of airborne dust, which induced fears in the locals of consequential health issues, and thus enhanced intentions of removal from the area. As, after the catastrophe, the chances of selling the houses in the area decreased, the general feeling of well-being was also diminishing in local communities due to their forced inability to leave.

The man-made environment of the entire flooded area was severely damaged. The value of the real properties of the directly affected - whose gardens or dwellings were inundated by red sludge - has been assessed by the state. In case the owners did not agree with the assessment, they could ask for a repeated estimation of loss. After static analyses, it was centrally decided to demolish all the damaged buildings, and the inhabitants could choose from three courses of compensation as regards homing. Most of the damaged buildings had to be demolished - even if the red sludge impacted only the outside of the base of the house because of the extremely strong alkaline nature of this substance, which, absorbed into the building material, could have caused static problems later on. Instead of the demolished buildings, on the basis of their value, the owners could choose from the following options: move to a used house in the same settlement, move to a used house 
somewhere else in the country, or move to the new residential area, built expressly for this purpose. In the case of those moving to the residential area, the government made efforts to make the new environs as familiar as possible. For this reason, the affected could choose their own plot - in order to preserve the former neighbourhood structure as much as possible, by way of "reconstruction" -, their preferred plan for the house and also the panellings.

The indirectly affected - all the inhabitants of the settlements -, however, received no compensation. After the disaster, many would have liked to leave the area, which was deemed dangerous, and the social and architectural structure of which was altered. However, most could not do this, as they did not get state funding for the removal, and the possibility of individually selling houses in the affected area was severely reduced.

The red sludge disaster had severe impacts on the local society as well. Even if we only consider the damages which can be expressed in numbers, it is clear that the social effects of the disaster require special attention. In the three, most severely affected settlements - Devecser, Kolontár and Somlóvásárhely - ten people died, and approximately 430 were injured, 262 houses were demolished, thus forcing their former inhabitants to move to different parts of the village or even the country, and two new residential areas have been established, with 87 houses in Devecser and 33 houses in Kolontár. On the whole, the red sludge induced profound changes in the lives of about 360 families. The changes of the community can be observed on several levels: family, friends, neighbourhood, and even settlement level.

\section{Materials and Methods}

\section{Question of Analysis}

I conducted the research for this study at two times in Devecser, using the life story interview method. The first period of data collection took place from 12-27 November 2010, and the second from 22 August to 13 November 2013. As in the first recording period, the identification of the directly affected was extremely difficult, the members for my sample were selected using the "snowball" method. In the second round of interviews, I applied the same method. I endeavoured to talk to some individuals in both sampling periods. In the first set, I made 14 life story interviews, and

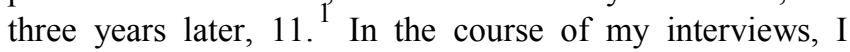
looked for people directly affected in the first place, and in 2013, I tried to interview persons from all the newly formed groups, namely, those who stayed in Devecser but moved to the new residential area, those who moved to used houses in

\footnotetext{
${ }^{1}$ For the analysis, I could use a pool of 70 further interviews, which were taken between 22 August and December 2013. For these, I owe special thanks to the students of the Sociology and Social Studies Department of the Pázmány Péter Catholic University. In this study, these interviews were only used as background material, detailed analysis was only performed on the 25 interviews recorded by myself.
}

other parts of the town, and those who left the town. In my research, I also contacted some indirectly affected people, as their narrative shed light on some typical features expressly connected to the narratives of the directly affected. In the course of my research, I studied the middle aged and elderly inhabitants, their ages varying from 33 to 73 years.

In the course of the analyses of the interviews, we will see that even three years after the disaster, there are significant differences in the level of trauma procession among the victims. In my analysis, I point out those social factors and circumstances, which, apart from personal resilience, influence the present well-being of the affected and their relations to the disaster.

When analysing the recorded material, the question to be answered was: what types of solving and processing strategies were "applied" by the interviewees in the years following the disaster?

\section{A Conceptual Clarification of Trauma}

The concept of trauma has become strikingly significant in the twentieth century. As in this period of time, several historical events occurred, in the course of which individuals or entire communities suffered, the importance and the difficulty of relating, understanding and socially acknowledging the endured events became conspicuous. The word "trauma" summarizes these experiences. By the end of the century, scientific studies concerning these events became more numerous, and this tendency continues to this day. Among the works of sociological trauma research, many examine experiences perceivable on the international level. The most frequently studied, traumatic events of the twentieth century are the World Wars, the Holocaust, and the changes of the regime in ex-communist states (see eg. [2-7]). Beside these, expressly Hungarian traumas of the twentieth century have also been thoroughly studied, such as the deportations, or the memories of participants in the 1956 revolution (see eg. [8-15]). Apart from such historical traumas, the research of traumas emerging from natural or industrial disasters is becoming increasingly prominent (see eg. [16-22]). As of 11 September 2001, traumas caused by traumatic events committed by humans - acts of terrorism are also becoming a topic of sociological interest [23]. Events similar to the above listed are innumerable, and they all have one indisputable point in common: their traumatic character. The proper understanding of the word "trauma", precisely because of its presence in our lives, is inevitable.

A detailed conceptual approach to trauma from a sociopsychological point of view can be found in Erös[24]. The word "trauma" was originally coined as a medical term, indicating a physical injury. The term entered the sphere of psychology in a similar manner: psychological trauma means,

\footnotetext{
2 The term ,indirectly affected" refers to all the inhabitants of Devecser, who had not suffered personal material or health damage. This terminology is also applied in other studies with similar topics. [1]
} 
as an analogy, a spiritual injury. The scientific introduction and acceptance of this term is mainly attributed to Sigmund Freud. At the beginning of the 1900's, focusing on the concept of psychological trauma, he launched his trademark approach, which is of great importance to this day: the psychoanalytic school. According to Erös, medical and psychological trauma have one important feature in common: their signs can be either easily recognised, or be shown by diagnostic means [24]. Scholars of the historical sciences were the first to borrow the term from the psychoanalytic school [25]. Apart from their physical or psychological nature, there are other bases for classifying traumas. Within the group of psychological traumas, Heller[25] distinguishes three categories: structural traumas are experienced by every individual during their lifetime, for example, according to Freud, the birth experience. The second category is that of historical traumas - such as those mentioned above -, which originate from a historical event, and the members of a community interpret them with the help of narrations. The third category is that of individual traumas, which means any type of personal affliction. Some traumatic events lie in the intersection of more categories, and can be interpreted, for example, as historical and individual at the same time [25], such as the Holocaust or the 2010 red sludge catastrophe in Hungary. Traumatic experience can be defined in several ways, but the definition must contain reference to the individual's or group's exposure to powers - the nature of which are inconceivable to the sufferers - threatening their existence, and their helplessness in the face of them [25].

Psychological trauma is also an object of social sciences, as it is inseparable from its social context. The importance of the social environment clearly appears in the phenomenon that the accounts of traumatic experiences of different individuals belonging to a single social group show similarities, which are typical to the group in question. From personal trauma, the concept of collective trauma also directly arises. The origin and the consequences of traumas are of a social nature, and from the consequences, further psycho-sociological traumas -collective traumas - often emerge. Collective trauma, as defined by Erős, is a series of events which, in its elements as well as a whole, traumatises the affected persons and their environments, obviously in various ways and to different depths [24]. Gábor Gyáni is a prominent Hungarian researcher of collective traumas and collective memory. In his works, he probes into historical traumas, which can also be interpreted as collective traumas (see eg. [11-12]). Gyáni practically considers the second half of the twentieth century - especially the period following the Second World War - as a time of collective traumas [11].

An important characteristic of traumas is that in their wake, the foundations of life partially or entirely disappear, not only materially, but also in social and cultural aspects. They are also of fundamental significance in the sufferers' lives, as they threaten their entire existence, and form an indelible part of their future life histories, integrated into them as fatal turning points [26]. When an individual becomes traumatised, his memories of the event will refuse normal procession and incorporation into the narrative life story. This is also apparent from the narration of the affected. Although the memories are present in the narrations, they appear as separate elements or pictures, and the narrators are not able to reflect on their emotions about them. In Erös's words: in the narrations, these events cannot be "represented", only "re-presented", i.e. merely their details replayed. To put it differently, the "essence" of the story cannot be seized [27]. In the case of people suffering from PTSD, these mental pictures keep repeating, not intentionally, but in a compulsive manner. Daniel L. Schacter emphasises that traumatic - or simply emotionally upsetting - memories, as well as other memories, are prone to distortions as time goes by. Generally, only small details get modified or lost, the core of the memory, however, remains intact [28]. Another important characteristic of traumas is clearly apparent in my analyses of the interviews: traumatised individuals often seek shelter and hope for the improvement of their circumstances from activities which, in reality, distract them from the profound ways of solution [24]. A very widespread manifestation of this phenomenon is the suppression of the traumatic experience. According to Schacter, it is typical of so-called "stubborn memories" among them, traumatic experiences - to resurface for an extended period of time, even against the person's will. In his opinion, the elimination of these resurfacings can be promoted by therapies based on sharing the trauma with others [29]. The problem of the "unspeakableness" of traumatic experiences is closely related to the phenomena discussed above. Dan Bar-On, examining the problem, emphasises that even "normal" emotions are difficult to express - and in the case of emotions connected to traumas, this difficulty is even harder to overcome [30]. This has several reasons, but one point is of special importance: namely, that neither the narrator, nor the interpreter possesses a socially accepted manner of speech in which to express these contents. It is innate to traumas that they attack the coherence of the personal narrative identity, as they resist the interpretive facilities of the individual [27]. If, however, the person does succeed in interpretation, and the event does become incorporated into the entire life story, it changes the identity of the individual. So the effects of a trauma destroy and rebuild the identity of the affected at the same time, creating, even after proper procession, a traumatised identity [27].

The better to understand the meaning of personal and collective trauma and their underlying factors, Kai $\mathrm{T}$. Erikson's[31] study on the social effects of a black sludge spill is of great use. The analysis introduces a rural area, where the individual was closely integrated in the local community, and neighbourhood connections were valued high. The disaster affected most of the inhabitants directly: from a population of 5000,125 people died, and the homes of 4000 were lost [31]. Erikson's work presents five characteristics of both personal and collective trauma. According to this study, a typical feature of personal trauma 
is the "mental numbness" appearing after the ceasing of immediate danger to life. Besides, experiencing death so closely contributed to the development of trauma, as the experience was large-scale and unexpected. The witnessing of the loss of material property - home, commodities, objects of great personal value - had similar effects, as those had become part of the identity. Experiencing the loss of the usual order also promoted the development of personal trauma. The fifth factor is survivor guilt, about their surviving when others have not [31]. Collective trauma manifests here as the loss of the common way of life. This means that one of the signs of trauma is that the general sense of well-being among those affected deteriorates, and parallel to this, deviance rate increases. For the locals, it became a kind of norm to regard the day of the disaster as the last day of life. A sense of loneliness, originating from the loss of the former community, appeared on the community level. It was also a general phenomenon that the individuals perceived their incapabilities more forcefully than their capabilities. A permanent sense of fear also became characteristic of the community [31]. As we can see, accentuated by Erikson's list of characteristics, in cases when personal and collective trauma are present parallelly, the procession of the traumatic events also has to take place on a community as well as a personal level, so that order may be re-established.

Related to the topic of traumas, the examination of the operation of memory also inevitably presents itself. Its significance has long been recognized; in fact, the concept can be traced back to the founding fathers of sociology [33]. The first author, however, to deal expressly with the workings of memory was Maurice Halbwachs, followed by several others, among whom Jan Assmann and Paul Ricoeur stand out, because of their theoretical impact. Today, an ever-increasing number of researchers study this subject, and in the past years, several Hungarian reviews of a high standard have also been published (see eg. [33-35]). Basically, memory types can be divided into three broad branches: autobiographical, social or collective, and historical memory. In her 2015 study, Éva Kovács describes the interconnectedness of the operations of the three; a novel approach, even in the international field [33]).

The concept of collective memory often emerges connected to trauma research. The reason for this is that collective memory is a type of memory which is shared by a small or large group of individuals. Its significance lies principally in its enabling the social communication between the members of a group with shared history. Social representations ${ }^{3}$, which promote this type of communication, are produced during the communicative process. Another important feature of the operation of the collective memory

\footnotetext{
${ }^{3}$ The concept of social representation, as defined by Serge Moscovici[36]: ,Social representations form a set of concepts, statements, and explanations that the person in the street uses to confront daily experiences, sot that he or she may understand these experiences and give them meaning. [...] In industrialized societies, social representations are equivalent to the myths and belief systems of traditional societies."
}

is its function in connecting the past with the present. Gyáni expresses this capacity poetically: "this past has not passed yet", followed by the statement that "the past of the twentieth century is continuously with us, permanently lurking here as an experience, preserved by memory, either articulate or waiting to become so" [11]. In the same way, collective memory lives on also in societies, related to the common past and historical deeds of the community in question. The symbols of this common past are preserved by museums, memorials, national holidays, and other reminders [5]. Pierre Nora[37] published one of the most important books about the sites of memory, not only as geographical spots, but also various reminding symbols.

On the basis of my definition expanded above, it is obvious that the concepts of trauma and collective memory often go hand in hand. In the case of traumatic events, the incidence typically reaches far beyond the former conceptual frameworks - as it exceeds our knowledge based on everyday experiences, and its social representations are not yet formed -, thus those afflicted cannot express the events by words. This means that the survivors' narrations, in which they could relate their experiences, cannot become a part of the social communication. After such traumatic events, collective memory itself gets modified, but this requires an exceedingly long time. Jan Assmann gives two types of collective memory: communicative and cultural memory [38]. According to Assmann's definition, this flexible type of collective memory which is modified after a traumatic event is termed communicative memory, as it represents the memories of the recent past, which are shared by all contemporaries [38]

Following the definition of Erös - according to which collective memory is based on common experiences -, we may arrive at the conclusion that, apart from society as a whole, that group of people who have shared a traumatic experience also develop some type of common knowledge or collective memory. It is possible that, for reasons expanded above, the events are "unspeakable" for them as well as others, but in their personal memories, the disastrous events leave similar traces. This, however, separates them from the majority of society, and we may presume that they will develop a separate collective memory, which differs from that of the majority. This theory is supported by the explanation of Keszei[34] and another hypothesis of Erös[24]. According to Erös, collective traumas become "collective" because individuals experiencing personal traumas find themselves in similar situations and society regards them similarly. This is the trait that creates a sense of common experience among them. After some time, it would be useful to examine the memories of those personally affected by the red sludge disaster from this point of view, and compare them to the collective memory of the majority of society. ${ }^{4}$

\footnotetext{
4 The analysis of Pék[39] partially covers this topic, presenting the memories about the disaster of those not affected.
} 
When observing the meaning of the expression traumatic event, we can again come to the conclusion that such events always exceed the frameworks of everyday life. Baráth[40] sums up the events which may become traumatic. A common trait of these is their extraordinary and upsetting nature, regardless of their taking place on the personal or the group level. Such events include threats to life, threats to personal physical integrity, severe injuries, physical violence against the loved ones, physical devastation of home or a community space, and witnessing the murder, injuring or physical abuse of others [40]. From this list, several items were present at the red sludge disaster: threat to life, threat to personal physical integrity, severe injuries, and the loss of living space. This also underlines the traumatic character of the red sludge disaster.

Traumatic events or disasters are typically followed by the usually easily recognizable symptoms of the above mentioned condition, post-traumatic stress disorder or PTSD. As I show in the analytical part of my study, these emerged in the case of the red sludge disaster as well. Baráth[40] distinguishes three types of PTSD symptoms: continuous replay, continuous escape, and continuous tension.

The symptoms of continuous replay include repetitive nightmares, obsessions, and repetitive memories, acute stress reactions against certain details of the original event, for instance colours or smells, loss of memory concerning the other participants of the event, and long-term cognitive disorders.

The symptoms of continuous escape include the shrinking from thoughts and dreams concerning the traumatic event, situations reminiscent of the event, and related communication, concentration problems and the reduction of interests.

Finally, the symptoms of continuous tension include the disturbance of the rhythm of wakefulness and sleep and vegetative disturbances in the period of sleep, permanent irritability and outbursts of wrath or hatred, and the sense of general restlessness or extreme alertness [40].

As mentioned above, the reason why the procession of trauma is a very difficult - often even inextricable challenge is that the mental pictures determine very strongly the personal memories regarding the event. There are examples where the sufferers succeeded in coping with the trauma, but this often involves the help of professionals (psychologists). The strategies for personal trauma procession can be divided into three groups. Summing them up briefly: the first is the positive strategy, when the affected person integrates the events successfully into his personality in four to six months, feels no guilt because of them, and does not view them as the determining factors of his future life, only as experiences. To achieve this, psychologists usually teach the affected person the method of reframing, which means viewing the events from a new perspective, making its sense, possibly even its positive consequences easily discernible. The second strategy may be termed negative, as in this case, the person goes on feeling unable to control the external or even internal events. The third option is the functional strategy. In its course, the individual plays an active role in the amelioration of his own condition. This involves an explicit attention payed to the quality and the changes of the condition, and a deliberate effort for its improvement [40].

\section{Trauma and Trauma Procession after the Red Sludge Disaster}

\section{Result from 2010}

The first stage of interviews was recorded very shortly after the event. At this time, it is certainly too early to talk about genuine trauma procession. In the theoretical introduction, I already mentioned the fact that when an individual is faced with a trauma, the former interpretive frames cannot be applied to understand and process it. The formation of new interpretive frames, which enable the (partial or entire) procession of the trauma, and make it possible to integrate it into the life story, take a considerably longer time - or, in fact, may never happen.

The question may arise whether the red sludge disaster should be viewed as a genuinely traumatic event, or rather, in the narrations of the interviewees, merely an experience of anomie can be perceived. In professional literature, there are many useful hints regarding the events which may have traumatic effects. The sludge spill meets several such criteria, mentioned above. It can be interpreted as a traumatic event not only on the personal, but also on the community level, as this disaster largely exceeded everyday experiences, meanwhile threatening the existence of the individual as well as the community itself $[5,24-25,31,40]$. Several, already mentioned features regarding the contents of the narrations also justify the event's traumatic interpretation on both levels. On the personal level, the experience of a threat to life and witnessing the loss of property both point this way. The overestimation of incapabilities in the identities of the affected, and the fact that the former community - especially the neighbourhood relations - have been destroyed indicate the collectively traumatic nature of the event. All this causes a negative change in the mood of the narrators. The disaster also undermined the general sense of safety in the entire local community.

The state of the trauma not yet having been processed in November 2010 was indicated by several characteristics, mentioned above: the depiction of the disaster dominates the entire narrative, while retaining a "freefloating", episodic feature, the post-disaster identity is mainly negative, future prospects are in several cases absent, and the symptoms of PTSD are present. In spite of the fact that real procession had not yet taken place, some behavioural traits promoting the acceptance of the traumatic situation, social re-integration, and the development of a more positive self image and future prospects, did already appear. We may term these "procession strategies". The fundamental question of this 
paper, then, is this: based on their life story narrations, what types of solving and processing strategies did the interviewees "apply"?

In this regard, the short period of time elapsed since the tragedy can be divided into three distinct phases. In all three of them, some definite similarities appear in the behaviour of those affected. The first phase started directly with the occurrence of the disaster, and lasted till the escape from the perilous situation. We can call this the phase of connecting. At this point, the first reaction of the survivors was to contact people of importance - mainly family and neighbours either by phone or in person. The aim of this was the ascertaining of the safety of the persons belonging to their primary social sphere. As demonstrated in one of the interviews:

“(...) now here we were, with all this, I was looking for the older people, to see what will become of them. (...) Then, that night we got dressed, went out, looked about, searched for people." (2010. Woman, age 67, married, lives with husband in their Devecser home, pensioner)

As an answer to this, close and distant relations began arriving at the site of the disaster in a short time, which was an important resource for the affected in the next phase, which may be called the cleaning phase. In the following two or three weeks, the only possible solution in the eyes of the affected seemed to be the cleaning of the house and gardens - they did not yet know that all the houses will eventually be demolished. This activity evoked a high level of solidarity and collaboration, from other members of the family, the local community, and the entire society. This experience probably promoted the trauma procession later on. An interviewee looks back on these times:

"For two days I thought that in a week we come back, clean it all. But we tried to push it out, but that red trace remained everywhere. (...) Well, first I was washing up all the time. When for instance the nut grinder, for hours in cold water. Because there was no hot water anymore. (...) These shiny pots, we just scrubbed and scrubbed them too." (2010. Woman, age 66, widow, two adult children live separately, the third in her home in Ajka, pensioner)

In the third phase, which began about two weeks after the event and was still in progress at time of the interviews, the behaviour of the affected was not so homogenous. Nevertheless, some general behavioural patterns, new habits can be distinguished, which were supposed by the interviewees to help to solve the situation (with varying degrees of success). There are six general factors influencing the personal trauma-solving strategies. From these, more than one may act simultaneously, in the case of a single person. The first such factor is 1.) work, which - after the cleaning of the house - makes it possible for the affected to pay attention to other things, apart from the anomies and their own, seemingly hopeless situation. This includes not only payed occupation, but all activities that occupy the individual, such as domestic chores or administrative tasks.

When faced with their own, insoluble problems, many people find a sense of usefulness in 2.) altruistic activities, which help them to get over the difficulties. This usually looks after family members, but often manifests in helping other affected individuals.

The next strategy is that of closing off, when the affected individual 3.) secludes herself from reminders. This may mean not only the deliberate avoidance of the damaged environment, courtyard, house, or even the entire settlement, but also a complete isolation from the recollection of the events. The danger, however, that the lack of facing the event hinders procession later on, is inherent in this attitude.

The fourth strategy may lay the foundations for a positive view of the future. This is 4.) planning of the future home. In the eyes of the people who show this attitude, the present seems to be only a transitional period between the happy past and the serene future. The following, longer extract is an example to this attitude. This text also shows that in her vision of the future, the narrator strives to re-establish the entire past community structure.

"Then I recruited some friends to the 'eighth block', so as to have familiar faces around us. They made plans for nice little houses. They showed me the drawings, and I chose one right then. We have the contract, everything. (...) Well, I am glad and I am sad. I am glad that it is all brand new and very nice and comfortable. But it is so very far off. (...) To come back here, it is too far off. Four kilometres. (...) Once we have the garden, we will be all right. There will be no need for sleeping pills nor anything else." (2010. Woman, age 67, married, lives with husband in their Devecser home, pensioner)

The final two strategies are similar. The first is when a 5.) strong personality stands by the affected person (usually the husband). In the other case, 6.) a stranger fills this role, such as a psychologist or a solicitor. The supporting role of the other person in both cases manifests in the help with decision-making and offering of emotional comfort.

In summary, there are three distinct phases in the initial period of trauma processing. These tend to be general to all those affected, in time and also in form, and can be clearly distinguished.

\section{Results from 2013}

When proceeding to the interviews of 2013, we can still observe the most general procession methods, which had helped the affected in the three years following the disaster, to be able to put the negative consequences of this traumatic event behind them. In the two broad topics discussed above, we have introduced several elements which promote the procession of the trauma. The most important of these, one of the corner-stones of the formation of the "survival identity", is the decision to deliberately move on. In the narration of those who had made this decision, several traits indicated 
that trauma procession had begun or was even completed.

The question of the event's traumatic nature is worth contemplating again in 2013. The disaster of 2010 has above been definitely established as a traumatic event, both on the personal and on the community level. In the narrations recorded in 2013, on the personal level, we can still find statements indicating that during the sludge spill, the entire life as known earlier was lost, or at least changed, and a new life had to be started. The sense of the loss of former life can be traced in the following two excerpts:

"The whole thing, that there is no house, no nothing, everything is gone. One used to have a shelter there. The house, I put the baby to bed. One goes home to it. Shelter. All of a sudden, everything you built, all in a few minutes.." (2013. Woman, age 36, married, lives with husband and three children in a used house in Devecser, housewife)

"You must not get lost in this, that then this and then that. Here is the new thing, you have to live with it now, I myself try to stand for this all the time." (2013. Woman, age 54, one adult daughter lives separately, lives with partner in the residential area, works at a hatchery)

However, several narrations show that despite all this, some have succeeded at trauma procession. In their cases, the entire life story is not dominated by the disaster any more, capabilities get a proper representation in the identity, they are satisfied with their present situation, and they have developed prospects for the future. But whether they view the disaster as an event that tore their lives apart, or as a means for a fresh start, in all the narrations this event is represented as a crisis which became - in one way or another - a turning point. Here, we may be reminded of Erik Erikson's theory on psychosocial development [32], where he depicts the progression of the phases of the formation of identity as a series of crises - traumas - and the coping thereof, a process at every stage of which something new develops. The examples for this are the situations where the individual can accept a new community (neighbourhood, workplace, or family), or a new lifestyle (new home, different part of town, other settlement, or a change of employment). Because of the measures taken after the disaster (compulsory removal), these situations occurred in the lives of every affected individual, even where the life story indicates the completion of a successful trauma procession. So the crisis was present in their lives as well, but they possess some kind of a tool which helped them to get over it. In the course of analysing the interviews, it became obvious that personal trauma procession could only ever have taken place in a community. It is important to note at this point that family is the key community, the presence or absence of which is the most important determining factor for the success of trauma procession. However, being integrated into other communities - it may be any of the above listed: workplace, neighbourhood, other - also promotes procession. In all of those who were not yet able to start trauma procession, secondary traumas were also present, parallel with the lack of belonging to a community, thus missing its support. These individuals got stuck in the phase of damage, to which the formerly developed victim-identity is still attached.

If we ask whether the disaster can be treated as a collective trauma in 2013, on the basis of the interviews, the answer is clearly affirmative. This is indicated by the fact that, after the sludge spill and the disruption of the neighbourhood structure of the affected area, locally, further social decomposition took place. The signs of this are the communal problems present in several settlements (e.g. envy, discord, isolation). Further, secondary traumas affecting the whole town of Devecser also deepened the collective trauma. These secondary traumas include alterations of the town structure (e.g. new residential area, memorial park), the extreme change of the townscape (e.g. renovation or reconstruction of communal spaces, removal of administrative offices), and the changes of the spatial distribution of the inhabitants (e.g. the settlement of Romas into districts formerly exclusively inhabited by Hungarians, the mixing of those directly affected with those indirectly affected, former inhabitants that left the town, victims living separately in the residential area). From Devecser, small-scale civil organizations and small communities are basically absent (or very few). As these should be the basic units to help processing the trauma triggered by all these changes, this support is practically non-existent in the area. ${ }^{5}$

The reactions triggered by the disaster and the attempts at procession can be either behavioural or mental. In 2010, directly after the event, three phases could be distinguished, which were different regarding trauma procession methods. In the first two of these, only behavioural elements, i.e. various activities were present as means from which the affected hoped consolation. First, they sought contact with their acquaintance, later, they cleaned up. In the third phase, some emotionally supportive reactions could be discerned, such as confidence in a stronger person. In 2013, the interviewees related that they still applied the activities which first appeared in the third phase, and from which they then had expected relief - for example, burying themselves in work so that they did not have so much time to contemplate the damages, or whiling away their time by helping more to their children. However, there are two elements which are present in a similar way, in all of the interviews. Both are connected to the former dwelling place. The first is the experience of the demolition of the old house, and the second is their relation with the memorial park. I asked all the interviewees - in case they did not relate this by themselves - about their attitude towards the memorial park, which is located on the site of their former neighbourhood.

\footnotetext{
${ }^{5}$ Here, let me thank Annamária V. Komlósi for our conversation on the importance, and, in this case, absence of small communities. The interview has been recorded on 05.02.2016.
} 
As regards this park, most of the narrators were of the same mind: they refuse to visit it, several of them even the see of it. This relation is a typical behavioural reaction. An attempt at trauma procession, the basis for which is isolation from objects reminiscent of the disaster, and which was already present in 2010. Some interviewees, however, did visit the memorial park a few times, but as it had distinctly negative emotional effects on them every time, they ceased to go again. In their words, about their habits and emotions regarding the park:

"After that, I think we went twice there with my partner. He said he wouldn't take me there anymore, as it always broke me down. (...) This was in 2011, that we used to go back. Since then, we haven't been there. (...) When you stop thinking positive for a moment, then you always fall a little." (2013. Woman, age 54, one adult daughter lives separately, lives with partner in the residential area, works at a hatchery)

"After church, they go out there and stand about for a while. (i.e. her acquaintance, in the memorial park) This is the way they remember. But I can't do this. This is how they relieve their tension. And I don't relieve it anyhow." (2013. Woman, age 58, married, three adult sons, lives with husband and the family of a son in Noszlop, farmer)

A basis for this avoidance behaviour may be the fact that the affected individuals' last personal memory about this site is the demolition of their former homes. This experience is present in several narrations as though they had witnessed a murder. A few excerpts to demonstrate this phenomenon:

"The sight, when they demolish a house, and when it's done, the excavator stands on top of it, work completed, on top of the ruins, as if to say now you are mine. This is horrible. My heart is still racing at the memory. These things cannot be forgotten." (2013. Woman, age 58, married, three adult sons, lives with husband and the family of a son in Noszlop, farmer)

"Then they destroyed it. It was awful to see. Sharp, strong - with a machine. In no time at all, the house was demolished. It was horrible to see this." (2013. Woman, age 70, widow, three children live separately, lives in a used house in Devecser, pensioner)

"I made a bad decision, I decided to watch as they demolish it. I stood there by myself. I watched as the excavator bites into the house. It was like biting into my own heart. The next moment, when I came to my senses, I saw the excavator, standing on top of the house. They smashed it to dust in no time at all." (2013. Woman, age 54, one adult daughter lives separately, lives with partner in the residential area, works at a hatchery)

This, as we see from the narratives, was such a powerful negative experience that we may assume it having acted as a secondary trauma. The injured do not visit the park, because they are afraid of the emotional effects of the memories triggered by the site. This avoidance behaviour, however, probably does not promote real trauma procession. As deliberate facing of the new situation helps to cope, so would in all probability getting habituated to the site, and integrating it into the everyday scenes of life.

The other procession strategy involves attempts on the mental level. Concisely, this means that the injured person tries to incorporate the traumatic experience among his other experiences by putting it into a new interpretative framework, which helps to put it into words, and, later, accept it. These frameworks may arise either from personal or from historical knowledge. In my interviews, I found two types of these explaining frameworks. The first compares the experiences to the natural, biological functions of life. Only a few examples can be found for this, but those make the sufferer capable of expressing their feelings in words, and thus integrating these events into the narration - and also, the identity. One of the examples is an interviewee who, after having got caught in the flood, managed to escape, and could even help her neighbour. In her narrative, she compared this experience to giving birth:

"But then I got such an impulse, I can't say how it was. Like when a woman gives birth and the child - I still say that hormones must have been released. I can't explain it. It was such an impulse. It was working on in me all the time, that this has to be solved, fended off. Come what may, I have to come out winner. I didn't panic. It was exactly the opposite." (2013. Woman, age 64, divorced, two adult daughters live separately in Pula, pensioner)

Another interviewee compares the way she parted from her old lifestyle after the disaster to grieving:

"Black trousers, black shirt, black coat, black boots. It was nearly like grieving. I couldn't think of putting on a red coat. Because it's harsh. I think I expressed my own mood, my inner life this way." (2013. Woman, age 58, married, three adult sons, lives with husband and the family of a son in Noszlop, farmer)

In fact, the mental representations in which the demolition of the houses was associated with murder provide a similar type of interpretation to the narration of the events.

In the other interpretative framework, which manifested more often, the narrators compare the experiences of the disaster or its aftermath to a historical trauma. The affected often introduce the anomic or fearful circumstances with a vision of war; however, there is one factual historical experience which is worth highlighting separately, as there are some among the affected who parallels their experiences expressly with this historical event: Auschwitz. To this type of interpretation, we find an example even in an interview of 2010:

"There is this one thing that troubles me, the armed police force. This is awfully disturbing. As if we were in Auschwitz. With machine guns on their backs. 
Outrageous. (...) I was stopped at a street corner by a young police officer: where are you going? I tell him: I want to go home. (...) There was an old man beside me. He didn't let him home, it was five meters. He said: Now look here, my lad, if you shoot me now in the head, I still go home. There hung the machine gun on his back." (2010. 2010. Woman, age 67, married, lives with husband in their Devecser home, pensioner)

"...well, in the retirement home they washed us, there all our clothes, everything, there were young people and 80-year-olds. And there is not a picture of that anywhere. Well... it was perhaps like Auschwitz. What went on there. There. To pull off the clothes of an 80-year-old, entirely naked. Or the young. Well that... that. It still comes to my mind, to this day. It was terrible, terrible. (...) ... and who, who were in it to their necks, because they dared not come out of their houses, their skin peeled off. And they washed them there, and then came the helicopter." (2013. Woman, age 61 , married, two adult children live separately, lives with her husband in the residential area, skilled worker)

In the case of several interviews, the experiences are not directly identified with the Auschwitz events, but - even for the interviewer - via shared historical knowledge and the operation of the collective memory, this representation helps to interpret the words of the sufferers. This association is encouraged by the images of helplessness, mass nakedness, and "cruel", inhuman treatment. The texts below also support the appearance of these sensations:

"They came with an excavator. We sat in its bucket. Everything was streaming down on us. They took us in, and it's not that I'm a prude, but they made us undress there, in front of the other people. That's humiliating. They washed us with a hose. They didn't even bother with a curtain or something. And in a place like that. We were in the yard of the retirement home." (2013. Woman, age 64, divorced, two adult daughters live separately in Pula, pensioner)

"We went into the home (i.e. retirement home). They led us inside, for I was very weak. They took our clothes off. There were no sheets, no clothes by that time. They washed us. Then they brought us clothes and shoes, trousers, slippers." (2013. Woman, age 70, widow, three children live separately, lives in a used house in Devecser, pensioner)

\section{Conclusions}

In summary, on the basis of the interviews taken at two different points in time, the disaster can be deemed a traumatic event, on the personal as well as on the collective level. It has to be stressed, that the event itself (e.g. a disaster) is never considered as a trauma. Trauma means always the effect of the event on a person or on a community. Accordingly a case turns into a traumatic event for somebody, but doesn't for another person.

The reactions to the red sludge spill and the attempts at trauma procession can be divided into phases. On the personal level of trauma procession, the first reaction after the traumatic event is connecting to others. The second phase is the two or three week long cleaning in the house. After this period, the behavioural coping strategies were discernible, for example undertaking the role of the helper. At last the mental processing strategies appeared.

Real procession, however, is probably more powerfully promoted by methods in the course of which the affected contemplates the events in a new interpretive framework, which helps to put the experiences into words. The formation of such a framework requires a longer period of time than the appearance of behavioural strategies. There are more than one ways of making an experience expressible: one is comparing it with another, actual event, but it is also possible to visualize the happenings of a well-known - for example historical - event in the narration of the experience. This method also helps the interpretation of the traumatic event, and ventilation, this certain promoter of spiritual healing, can take place.

The attempts for the trauma processing on behavioural level are mostly useful to avoid remember the catastrophic event, but these are not proper ways for the real coping. Thus the processing strategies used on mental level are needed too.

An additional interviewing period would be conducive to observe whether the previous statement is valid: Are the mental interpretative frameworks really indispensable for real adaptation of such an experience?

\section{REFERENCES}

[1] A. M. Bartal, Z. Ferencz. A vörösiszap-katasztrófa társadalmi hatásai $=$ Social Effects of the Red Sludge Disaster, Argumentum Kiadó, Budapest, 2015.

[2] J. C. Alexander. Toward a Theory of Cultural Trauma. In: J. C. Alexander et al. (ed). Cultural Trauma and Collective Identity, University of California Press, Berkley, California, 1-30, 2004.

[3] B. Bettelheim. A végső határ = The Last Border. Európa Könyvkiadó, Budapest, 1999.

[4] B. Buda. A trauma szociális természete $=$ Social Nature of Trauma. In: T. Virág (ed.): Elhúzódó társadalmi traumák hatásának felismerése és gyógyítása, Konferencia = Recognition and Curing of the Effects of Long-Continued Social Traumas, Budapest, 1996. november 15-17, Animula Egyesület, Budapest, 107-114, 1997.

[5] F. Erős. A válság szociálpszichológiája = Sociopsychology of the Crisis, T-Twins Kiadó, Budapest, 1994.

[6] B. Giesen. The Trauma of Perpetrators: The Holocaust as the Traumatic Reference of German National Identity. In: J. C. Alexander et al. (ed). Cultural Trauma and Collective Identity, 
University of California Press, Berkley, California, 112-154, 2004.

[7] P. Sztompka. The Trauma of Social Change: A Case. In: J. C. Alexander et al. (ed). Cultural Trauma and Collective Identity, University of California Press, Berkley, California, 155-195, 2004.

[8] Zs. Bögre. Asszonysorsok: Ötvenhatos élettörténetek elemzése $=$ Fates of Women: Analyses of Life Stories of 1956, Ráció Kiadó, Budapest, 2006.

[9] Zs. Bögre. "My Generation is Quite a Sullen One...": Trauma and Remembering in Life Stories after 1956, Corvinus Journal of Sociology and Social Policy, Vol.3, No.1, 81-110.

[10] Zs. Bögre, S. Tulipán (ed.). Haza vagy otthon?: Georgiai magyarok emlékezete 1956-ról = Homeland or Home? Remembrance about 1956 of Hungarian People in Georgia, Hungarian Community Church of George, Gainesville, 2014.

[11] G. Gyáni. Az elveszíthető múlt: A tapasztalat mint emlékezet és történelem $=$ The Losable Past: The Experience as Memory and History, Nyitott Könyvmühely, Budapest, 2010.

[12] G. Gyáni. A magyar „emlékezet helyei” és a traumatikus múlt $=$ The Hungarian "Places of Remembrance" and the Traumatic Past, Studia Litteraria, Vol.50, No.1-2, 41-50.

[13] J. Saád. "Undesirable elements": Forced relocations 1950-53. The New Hungarian Quarterly, Vol.31, No.120, 109-118.

[14] J. Saád J. (ed.). Telepessors = Fate of Settlers, Gondolat Kiadó, Budapest, 2004.

[15] J. Saád. Hortobágy: A magyar Gulág = The Hungarian Gulag, Rubicon, Vol.21, No.6, 4-20.

[16] H. I-Chiao. Family Stress and Coping. In: S. J. Bahr (ed.). Family Research Vol. 1., Lexington Books, Toronto, 289-334, 1991.

[17] D. Parthasarathy. Social and Environmental Insecurities in Mumbai: Towards a Sociological Perspective on Vulnerability, South African Review of Sociology, Vol.40, No.1, 109-126.

[18] M. Reid - C. Reczek. Stress and Support in Family Relationships After Hurricane Katrina, Journal of Family Issues, Vol.32, No.10, 1397-1418.

[19] S. R. Lowe et al. Changes in Marital and Partner Relationships in the Aftermath of Hurricane Katrina: An Analysis With Low-Income Women, Psychology of Women Quarterly, 2012. 02.02

[20] T. J. Puleo - H. Sivak. Introdusction: The Ambivalence of Catastrophe, The Geographical Review, Vol.103, No.4, 458-468.

[21] A. P. Botey - J. C. Kulig. Family Functioning Following Wildfires: Recovering from the 2011 Slave Lake Fires, J. Child. Fam. Stud. No.23. (2014), 1471-1483.

[22] M. N. Riaz et al. Well-Being and Post-Traumatic Stress Disorder due to Natural and Man-Made Disaster on Adults. Pak. J. Med. Res., Vol.54, No.1, 25-28.

[23] N. J. Smelser. Psychological Trauma and Cultural Trauma. In: J. C. Alexander et al. (ed). Cultural Trauma and Collective Identity, University of California Press, Berkley, California, 31-59, 2004.
[24] F. Erős. Trauma és történelem: Szociálpszichológiai és pszichoanalitikus tanulmányok = Truma and History: Sociopsychological and Psychoanalytical Essays, Jószöveg Mühely Kiadó, Budapest, 2007.

[25] Á. Heller. Trauma = The Trauma, Múlt és Jövő Kiadó, Budapest, 2006.

[26] L. Tengelyi. Élettörténet és sorsesemény = Life Story and Fatal Turning Points, Atlantisz Kiadó, Budapest, 1998.

[27] J. N. Pintér. A nem múló jelen: Trauma és nosztalgia $=$ The Non Passing Present: Trauma and Nostalgia, L'Harmattan, Budapest, 2014.

[28] D. L. Schacter. Emlékeink nyomában: Az agy, az elme és a múlt = Atrail Our Memories: The Brain, the Mind and the Past, Háttér Kiadó, Budapest, 1998.

[29] D. L. Schacter. Az emlékezet hét büne: Hogyan felejt és emlékszik az elme? = Seven Sins of the Remembrance: How is the Mind Forget and Remember?, HVG Könyvek, Budapest, 2002.

[30] D. Bar-On. The Indescribable and the Undiscussable: Reconstructing Human Discourse after Trauma, Central European University Press, Budapest, 1999.

[31] K. T. Erikson. Everything in Its Path: Destruction of Community in the Buffalo Creek Flood, Simon and Schuster Inc., New York, 1976.

[32] E. H. Erikson. The Problem of Ego Identity, Journal of the American Psychoanalytic Association (1956), No.4, 56-121.

[33] É. Kovács. Az emlékezet szociológiai elméletéhez $=$ To the Sociological Conception of the Remembrance. In: P. Bodor (ed.). Emlékezés, identitás, diskurzus $=$ Remembrance, Identity and Discourse, L'Harmattan, Budapest, 237-260, 2015.

[34] A. Keszei. Jelentés, törés, identitás = Meaning, Breakage, Identity. In: Zs. Bögre et al. (ed.). Az identitások korlátai: Traumák, tabusítások, tapasztalattörténetek a II. világháború kezdetétől = The Limits of Identities: Traumas, Taboos, Stories of Experiences since the Beginning of Second World War, L'Harmattan, Budapest, 11-35, 2012.

[35] A. Keszei. Hely és emlékezet között $=$ Between Place and Remembrance. In: A. Keszei, Zs. Bögre (ed.). Hely, identitás, emlékezet = Place, Identity, Remembrance, L'Harmattan, Budapest, 52-73, 2015.

[36] S. Moscovici. Társadalom-lélektan: Válogatott tanulmányok= Psychology of Society: Selected Essays, Osiris Kiadó, Budapest, 2002.

[37] P. Nora. Emlékezet és történelem között = Between Remembrance and History, Aetas (1984) No.3. Online available from http://www.aetas.hu/1999 3/99-3-10.htm

[38] J. Assmann. A kulturális emlékezet: Írás, emlékezés és politikai identitás a korai magaskultúrákban $=$ The Cultural Memory: Writing, Remembering and Political Identity in the Early High Culture, Atlantisz Könyvkiadó, Budapest, 1999.

[39] Gy. Pék et al. Kollektív traumatikus eseményt követő kommunikáció vizsgálata. (A magyarországi „vörösiszap-katasztrófá”-val kapcsolatos információfeldolgo zás ás érzelmi reakciók) $=$ Analysis of Communication after a Collective Traumatical Event. (Information Processing and 
Emotional Reactions in Connection with the Hungarian „Red Sludge Disaster". In: P. S. Varga et al. (ed.). A magyar emlékezethelyek kutatásának elméleti és módszertani alapjai $=$ Theoretical and Methodological Bases of the Research of Hungarian Places of Remembrance, Debreceni Egyetemi Kiadó Debrecen University Press, Debrecen, 140-149, 2013.
[40] Á. Baráth. Kreatív terápiák a szociális válságkezelésben = Creative Therapies in Social Crisis Management. In: J. Kozma (ed.). Kézikönyv szociális munkásoknak = Handbook for Social Workers, Szociális Szakmai Szövetség, Budapest, 179-201, 1998. 